\title{
A dual isotope approach to isolate soil carbon pools of different turnover times
}

\author{
M. S. Torn ${ }^{1,2}$, M. Kleber ${ }^{3}$, E. S. Zavaleta ${ }^{4}$, B. Zhu ${ }^{1}$, C. B. Field ${ }^{5}$, and S. E. Trumbore ${ }^{6}$ \\ ${ }^{1}$ Earth Sciences Division, Lawrence Berkeley National Laboratory, Berkeley CA 94720, USA \\ ${ }^{2}$ Energy and Resources Group, University of California, Berkeley, CA 94720, USA \\ ${ }^{3}$ Department of Crop and Soil Science, Oregon State University, Corvallis, OR 97331, USA \\ ${ }^{4}$ Department of Environmental Studies, University of California, Santa Cruz, CA 95064, USA \\ ${ }^{5}$ Department of Global Ecology, Carnegie Institution for Science, Stanford, CA 94305, USA \\ ${ }^{6}$ Department of Biogeochemical Processes, Max Planck Institute for Biogeochemistry, 07745 Jena, Germany
}

Correspondence to: M. S. Torn (mstorn@lbl.gov)

Received: 29 March 2013 - Published in Biogeosciences Discuss.: 24 June 2013

Revised: 23 October 2013 - Accepted: 24 October 2013 - Published: 10 December 2013

\begin{abstract}
Soils are globally significant sources and sinks of atmospheric $\mathrm{CO}_{2}$. Increasing the resolution of soil carbon turnover estimates is important for predicting the response of soil carbon cycling to environmental change. We show that soil carbon turnover times can be more finely resolved using a dual isotope label like the one provided by elevated $\mathrm{CO}_{2}$ experiments that use fossil $\mathrm{CO}_{2}$. We modeled each soil physical fraction as two pools with different turnover times using the atmospheric ${ }^{14} \mathrm{C}$ bomb spike in combination with the label in ${ }^{14} \mathrm{C}$ and ${ }^{13} \mathrm{C}$ provided by an elevated $\mathrm{CO}_{2}$ experiment in a California annual grassland.

In sandstone and serpentine soils, the light fraction carbon was $21-54 \%$ fast cycling with 2-9 yr turnover, and 36-79\% slow cycling with turnover slower than $100 \mathrm{yr}$. This validates model treatment of the light fraction as active and intermediate cycling carbon. The dense, mineral-associated fraction also had a very dynamic component, consisting of $\sim 7 \%$ fast-cycling carbon and $\sim 93 \%$ very slow cycling carbon. Similarly, half the microbial biomass carbon in the sandstone soil was more than $5 \mathrm{yr}$ old, and $40 \%$ of the carbon respired by microbes had been fixed more than 5 yr ago.

Resolving each density fraction into two pools revealed that only a small component of total soil carbon is responsible for most $\mathrm{CO}_{2}$ efflux from these soils. In the sandstone soil, $11 \%$ of soil carbon contributes more than $90 \%$ of the annual $\mathrm{CO}_{2}$ efflux. The fact that soil physical fractions, designed to isolate organic material of roughly homogeneous physico-chemical state, contain material of dramatically dif-
\end{abstract}

ferent turnover times is consistent with recent observations of rapid isotope incorporation into seemingly stable fractions and with emerging evidence for hot spots or micro-site variation of decomposition within the soil matrix. Predictions of soil carbon storage using a turnover time estimated with the assumption of a single pool per density fraction would greatly overestimate the near-term response to changes in productivity or decomposition rates. Therefore, these results suggest a slower initial change in soil carbon storage due to environmental change than has been assumed by simpler (one-pool) mass balance calculations.

\section{Introduction}

Soil organic matter (SOM) is a complex mixture of substances having turnover times ranging from days to millennia (Trumbore and Czimczik, 2008). Although models with a limited number of pools or SOM categories do a good job of predicting steady-state carbon stocks, they may not be adequate for predicting responses to perturbation or climate change (Davidson et al., 2000; Derrien and Amelung, 2011). Increasing the resolution of soil carbon turnover estimates is important for understanding biogeochemical cycling of carbon, nitrogen, and other SOM-related elements, as well as predicting the response to environmental change (Schimel et al., 1994; Trumbore, 2000; Torn et al., 2009). 
Some studies using isotopic or stock/flow methods to determine soil carbon turnover times have used the simplifying assumption that SOM within one soil horizon represents a homogeneous, well-mixed pool with respect to decomposition (e.g., Raich and Schlesinger, 1992; Giardina and Ryan, 2000). However, organic materials in the soil have different decomposition kinetics depending on chemistry, location, and physico-chemical condition (Schmidt et al., 2011). For example, the proportion of SOM cycling with millennial turnover time can vary from zero to over $50 \%$, depending on mineral type, clay content, and soil depth (Torn et al., 1997; Masiello et al., 2004). This variation has a large effect on the calculated turnover times when soil carbon fractions cycling at different rates are averaged together (Trumbore, 2000). Although it is widely recognized that assumptions of homogeneity in decomposition kinetics are too simplistic to adequately model and predict soil carbon turnover (Trumbore, 1993; Davidson et al., 2000; Torn et al., 2009; Derrien and Amelung, 2011), in practice, it is difficult to adequately describe and model turnover of an immeasurable number of individual organic compounds. While there are models representing decomposing organic matter as a continuum of differentially behaving compounds (Ågren and Bosatta, 1987), more commonly ecosystem models operationally divide SOM into a limited number of pools. For example, the CENTURY model uses three pools designated active (annual turnover), intermediate (decadal-century) and passive (century-millennia) pools (Parton et al., 1987; Schimel et al., 1994).

Physical fractionation procedures separate SOM into pools of similar physico-chemical state based on aggregation, particle size, or density (Christensen, 2001; von Lützow et al., 2007). Density fractionation is applied to separate mineral-associated organic matter from free particulate organic matter (Sollins et al., 1983; Golchin et al., 1994; Crow et al., 2007; Moni et al., 2012). Organic matter in the light fraction (LF) decomposes more quickly than in the dense fraction (DF) (Sollins et al., 1984; Swanston et al., 2002; Marín-Spiotta et al., 2008). In three-pool models, mineralprotected carbon (typically parameterized with texture) is part of the passive fraction and the LF is treated as a mixture of active and intermediate cycling carbon (Trumbore, 2000). However, studies using isotopic composition to estimate turnover time of the LF (or free LF where occluded material is analyzed separately) often interpret the fraction data with a one-pool model (for example, as all fast or intermediate cycling). Theoretical considerations together with experimental evidence (Trumbore and Zheng, 1996; Swanston et al., 2005; Sollins et al., 2009) suggest that the DF is also too heterogeneous to be treated as one pool. In fact, the DF has shown rapid incorporation of both ${ }^{14} \mathrm{C}$ (Swanston et al., 2005) and ${ }^{13} \mathrm{C}$ (Bird et al., 2008) label from recent inputs, indicating that it comprises a fast-cycling component as well as older carbon. Sequential density fractionation (e.g., Sollins et al., 2006, 2009) has isolated fractions with differ- ent pools of old radiocarbon ages, but published studies have not observed or explained the rapid incorporation of new organic inputs. The same is true for "free light" and "occluded light" separations, which, while effective at separating SOM into fractions of very different ${ }^{14} \mathrm{C}$ values, have not isolated SOM cycling on annual timescales (Golchin et al., 1994; Rasmussen et al., 2005; McFarlane et al., 2013). We are not aware of a method to physically separate the light fraction into active and slow-cycling components, or to isolate the fast-cycling part of dense, mineral-associated SOM. Therefore, we tested a dual isotopic labeling approach to achieve a functional separation of soil density fractions into two pools with distinct turnover times.

Soil microbes are the principal decomposers in soil, influencing nutrient cycling, soil carbon stocks, and plant productivity. In conventional three-pool soil carbon models, microbial biomass is treated as part of the active or fast pool, which makes up less than 5 percent of the soil organic carbon and has turnover times in the range of years or less (Parton et al., 1987; Jenkinson, 1990). The isotopic composition of microbial biomass matches that of the substrates they utilize plus a discrimination factor (Dijkstra et al., 2006) and is useful for investigating microbial metabolism and substrate utilization (Kramer and Gleixner, 2006; Garnett et al., 2011).

The objective of our study was to contribute to the understanding of SOM dynamics by characterizing the heterogeneity of soil carbon turnover. We used the isotopic label $\left({ }^{14} \mathrm{C}\right.$ and $\left.{ }^{13} \mathrm{C}\right)$ from fossil-fuel-derived $\mathrm{CO}_{2}$ in an elevated $\mathrm{CO}_{2}$ experiment in an annual grassland combined with the ${ }^{14} \mathrm{C}$ "bomb spike" to investigate soil carbon turnover and pool structure. We investigated two soil physical fractions, the mineral-associated, dense fraction and the light fraction, and determined turnover times when modeled as two pools in each fraction. In the Jasper Ridge open-top chamber (OTC) experiment (Field et al., 1996), plant inputs increased under elevated $\mathrm{CO}_{2}$, although no change in soil carbon stocks was detectable (Hungate et al., 1997). Thus, we modeled with both steady-state and non-steady-state (i.e., increased plant inputs under elevated $\mathrm{CO}_{2}$ ) assumptions. We also studied soils derived from two very different parent materials, sandstone and serpentine. Finally, we applied the dual isotopic label to characterize the extent to which microbial biomass comprises older versus recently assimilated carbon and to estimate the fraction of heterotrophic respiration derived from decomposition of organic material fixed pre-experiment, employing the ${ }^{13} \mathrm{C}$ and ${ }^{14} \mathrm{C}$ label from the elevated $\mathrm{CO}_{2}$ experiment to quantify the amount of microbial biomass that was older than $5 \mathrm{yr}$. 


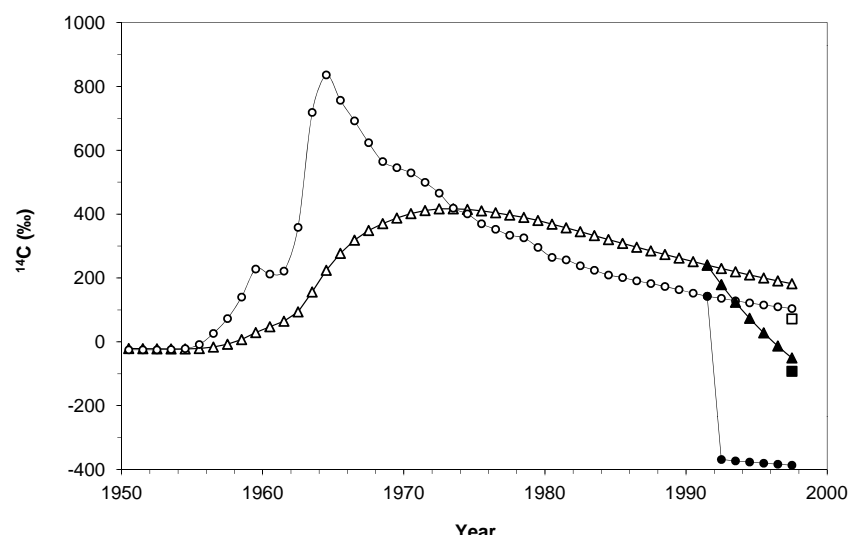

Fig. 1. Measured values of ${ }^{14} \mathrm{CO}_{2}$ in the ambient air of the Northern Hemisphere (open circles) and ${ }^{14} \mathrm{CO}_{2}$ in the air supplied to the elevated $\mathrm{CO}_{2}$ treatment (filled circles) compared to calculated ${ }^{14} \mathrm{C}$ values of soil organic matter in the control (open triangles) and the elevated $\mathrm{CO}_{2}$ (filled triangles) treatments for an arbitrary turnover time of $10 \mathrm{yr}$. Also shown are measured $\Delta^{14} \mathrm{C}$ values for the light fraction of sandstone topsoil $(0-15 \mathrm{~cm})$ in the control plots (open square, $\Delta^{14} \mathrm{C}=72 \%$ ) and the elevated $\mathrm{CO}_{2}$ plots (filled square, $\Delta^{14} \mathrm{C}=-92 \%$ o) in 1997 .

\section{Materials and methods}

\subsection{The dual isotope and inverse label approach}

Our approach takes advantage of the fact that the organic carbon entering the soil in the elevated $\mathrm{CO}_{2}$ experiment at Jasper Ridge, California, from January 1992 to June 1997 (Field et al., 1996) was inversely labeled with two isotopes, ${ }^{13} \mathrm{C}$ and ${ }^{14} \mathrm{C}$. In the case of ${ }^{14} \mathrm{C}$ this inverse labeling (dilution with ${ }^{14} \mathrm{C}$-free carbon) is superimposed on the enrichment of ${ }^{14} \mathrm{C}$ in atmospheric $\mathrm{CO}_{2}$ and photosynthate caused by nuclear weapons testing (Fig. 1). This bomb spike has been decreasing since it peaked in the early 1960s.

Most elevated $\mathrm{CO}_{2}$ experiments apply $\mathrm{CO}_{2}$ produced from fossil fuels. Because fossil fuels are ${ }^{14} \mathrm{C}$-dead and depleted in ${ }^{13} \mathrm{C}$ relative to ambient atmosphere, the assimilation of fossil-fuel-derived $\mathrm{CO}_{2}$ results in depletion of both ${ }^{13} \mathrm{C}$ and ${ }^{14} \mathrm{C}$ in plant tissues. For example, at Jasper Ridge the fossil fuel versus atmosphere values of $\mathrm{CO}_{2}$ were $\delta^{13} \mathrm{C}=$ $-35 \%$ oversus $-8 \%$, and $\Delta{ }^{14} \mathrm{C}=-1000 \%$ versus $+100 \%$ o in 1996 . The inversely labeled (i.e., isotopically depleted) plant carbon is transferred through plant mortality and exudates to the soil, where it gradually replaces older carbon (carbon fixed pre-experiment) that is cycling out of the soil. The degree to which soil carbon or a particular soil carbon fraction has incorporated the depleted plant signal indicates the proportion of soil carbon that has turned over during the course of the experiment (Fig. 1).

We estimate turnover times based on a linear donorcontrolled model of soil carbon cycling (Trumbore, 1993; Gaudinski et al., 2000; Torn et al., 2009), meaning that the amount of carbon decomposed is the product of the carbon stock $(C)$, a decomposition rate constant $(k)$, and the time interval $(\Delta t)$. The turnover time $(\tau)$ is the reciprocal of the decomposition rate (i.e., $\tau=1 / k$ ).

The Jasper Ridge grassland is dominated by annual plant species, allowing us to make an assumption that simplifies the modeling task, namely that all plant carbon inputs to soil in a given year have the isotopic content of that year's net primary productivity (NPP). This assumption is weakest in the subsoil, where some carbon inputs may have been leached from surface to subsoil over time. We also assumed that leaching and erosion losses from these soils are negligible, so that all carbon losses can be attributed to organic matter decomposition (alternatively, one could restate the turnover time as pertaining to all loss pathways rather than just decomposition).

The change in soil carbon stock between one year and the next is the difference between the inputs and outputs over that year. Thus, the amount of organic carbon present in the soil depth interval at a given time, as a function of the rate of plant inputs and the turnover time for decomposition, is

$\mathrm{C}(t)=\mathrm{C}_{t-1}+I_{t-1}-\left(\frac{\mathrm{C}_{t-1}}{\tau}\right)$,

where $\mathrm{C}(t)=$ soil carbon stock at year $t\left(\mathrm{~g} \mathrm{~m}^{-2}\right) ; \mathrm{C}_{t-1}=$ soil carbon stock at the year before year $t ; t=$ annual time step (y); $I=$ plant carbon inputs $\left(\mathrm{g} \mathrm{m}^{-2} \mathrm{yr}^{-1}\right)$; and $\tau=$ turnover time of soil carbon $(y)$.

An analogous relationship holds for isotopic content: the change in soil carbon isotopic ratio between one year and the next depends on the difference between the isotopic content of the annual inputs and outputs. The amount of ${ }^{13} \mathrm{C}$ can be expressed by multiplying the $\delta^{13} \mathrm{C}$ value by total carbon content:

$\delta^{13} C_{\text {soil }}(t)=\frac{\left(\delta^{13} C_{\text {soil }, t-1} \times C\right)+\left(\delta^{13} C_{\text {plant }, t} \times I_{t}\right)-\left(\frac{\delta^{13} C_{\text {soil }, t-1} \times C}{\tau}\right)}{C}$,

where $\mathrm{C}=$ amount of total soil carbon at steady state $\left(\mathrm{g} \mathrm{m}^{-2}\right) ; t=$ time step $(y) ; \delta^{13} \mathrm{C}_{\text {soil }}(t)={ }^{13} \mathrm{C}$ content of soil at time $t(\% o) ; \delta^{13} \mathrm{C}_{\text {plan } t}(t)={ }^{13} \mathrm{C}$ content of plant input to soil at time $t(\% \circ) ; I=$ input rate of plant carbon $\left(\mathrm{g} \mathrm{m}^{-2} \mathrm{yr}^{-1}\right)$; and $\tau=$ turnover time of soil organic carbon $(y)$.

In the case of ${ }^{14} \mathrm{C}$, a second loss pathway, radioactive decay, is added to the existing decomposition loss term:

$\Delta \Delta^{14} \mathrm{C}_{\text {soil }}(t)=\frac{\left(\Delta^{14} \mathrm{C}_{\text {soil }, t-1} \times \mathrm{C}\right)+\left(\Delta^{14} \mathrm{C}_{\text {plant }, t} \times I_{t}\right)-\left(\left(\frac{1}{\tau}+\lambda\right) \times\left(\Delta^{14} \mathrm{C}_{\text {soil }, t-1} \times \mathrm{C}\right)\right)}{\mathrm{C}}$

where $\Delta{ }^{14} \mathrm{C}_{\text {soil }}(t)={ }^{14} \mathrm{C}$ content of soil at time $t(\%)$; $\Delta{ }^{14} \mathrm{C}_{\text {soil }}(t-1)={ }^{14} \mathrm{C}$ content of soil at time $t-1(\%)$; $t=$ time step $(y) ; \Delta{ }^{14} \mathrm{C}_{\text {plant }}(t)={ }^{14} \mathrm{C}$ content of plant inputs at time $t(\%)$; and $\lambda=$ radioactive decay constant for ${ }^{14} \mathrm{C}$ $\left(0.000121 \mathrm{yr}^{-1}\right)$.

Under steady-state conditions, i.e., when annual plant inputs equal annual decomposition losses, there is no 
change in carbon stock from year to year. In other words, $\mathrm{C}(t)=\mathrm{C}(t-1)$. In that case, that term can be substituted into Eq. (1), yielding the following:

$I=\frac{\mathrm{C}_{t}}{\tau}=\frac{\mathrm{C}_{t-1}}{\tau}=\frac{\mathrm{C}}{\tau}$,

With the steady-state assumption for carbon stocks and constant rate of plant carbon inputs, the input term, $I$, can be replaced with $C / \tau$, greatly simplifying the equations used to solve for isotopic values over time. However, it is also possible to do this type of modeling without a steady-state assumption or condition.

To investigate the effect of non-steady-state carbon cycling on the type of analysis done here, we analyzed a case of increasing plant inputs over the time of the experiment, with a consequent increase in soil carbon stocks in the elevated $\mathrm{CO}_{2}$ treatment. To create a realistic scenario in the absence of direct observations of a change in plant inputs to soil, we used an estimate of the increase in active carbon pools, defined as the sum of plant, detrital, and microbial carbon pools, due to the elevated $\mathrm{CO}_{2}$ treatment. Hungate et al. (1997) estimated that active carbon pools increased $37 \%$ in sandstone soil and $25 \%$ in serpentine soil in the elevated $\mathrm{CO}_{2}$ treatment relative to the controls after the first three years of the experiment. Therefore, we ran our models under non-steadystate conditions for the elevated $\mathrm{CO}_{2}$ treatment: specifically, we increased plant inputs $(I)$ by $37 \%$ in sandstone soil and by $25 \%$ in serpentine soil during the experimental period (1992-1997) compared to steady-state conditions before 1992, but kept turnover times $(\tau)$ unchanged. The resulting predicted change in soil carbon stock was smaller than the reported detection limit given the high spatial heterogeneity in soil carbon at these sites, and thus this non-steady-state scenario is consistent with findings of no significant change in soil carbon stock (Hungate et al., 1996). To test the importance of steady-state assumptions for the results reported here, it would be equally plausible, if one had sufficient observational constraints, to consider a scenario in which decay rate constants change, for example due to changes in soil enzyme activities (Kandeler et al., 2006) or utilization of rhizodeposits versus other SOM (Cardon et al. 2001) under elevated $\mathrm{CO}_{2}$.

\subsection{Study site and soil sampling}

Our study was located in annual grasslands at the Jasper Ridge Biological Preserve of Stanford University, California, USA $\left(37^{\circ} 24^{\prime} \mathrm{N}, 122^{\circ} 14^{\prime} \mathrm{W}\right)$, in central coastal California. Two types of grassland, differing in plant species composition, productivity, and nutrient limitation, occur adjacent to each other on sandstone- and serpentine-derived soils. The moderately productive sandstone grasslands have welldeveloped soils and are dominated by exotic European annual grasses. The serpentine grasslands have shallow, poorly developed soils and lower productivity under a mix of ex- otic annuals and native forbs and grasses. In the Jasper Ridge elevated $\mathrm{CO}_{2}$ experiment (Field et al., 1996; Hungate et al., 1997), $0.3 \mathrm{~m}^{2}$ plots in open-top chambers were exposed to either ambient $(n=10)$ or elevated (ambient $+350 \mathrm{ppm}$, $n=10) \mathrm{CO}_{2}$ from January 1992 to June 1997.

Soil cores were collected in April 1997 from sandstone (015 and $15-30 \mathrm{~cm})$ and serpentine $(0-15 \mathrm{~cm})$ field plots, airdried, and dry-sieved $(2 \mathrm{~mm})$ for rocks and roots. Rock fragment content, defined as the weight fraction of mineral material that did not pass through a $2 \mathrm{~mm}$ sieve, was determined to be $6 \%$ weight for the sandstone soil and $41 \%$ weight for the serpentine soil. We sampled sandstone soil bulk density at $0-15$ and $15-30 \mathrm{~cm}\left(0.94\right.$ and $1.28 \mathrm{~g} \mathrm{~cm}^{-3}$, respectively) depths by taking volumetric samples from the side of a soil pit near midpoint of the respective depth interval with a Soil Moisture brand bulk density sampler. Samples were ovendried at $105^{\circ} \mathrm{C}$ before weighing. We also used bulk density data from Hungate et al. (1996), who sampled each plot once with a known-volume corer from the soil surface, to obtain bulk density samples in the $0-15 \mathrm{~cm}$ depth $\left(0.97 \mathrm{~g} \mathrm{~cm}^{-3}\right)$ in the serpentine grassland.

\subsection{Density fractionation and isotopic analysis}

We used density separation to isolate light (mainly particulate organic matter) and dense (mainly mineral-associated) soil carbon pools. Ten (10) g soil subsamples were suspended in $50 \mathrm{~mL}$ of sodium polytungstate (Geoliquids, Inc.) solution of $2.0 \mathrm{~g} \mathrm{~mL}^{-1}$ (sandstone) or $1.8 \mathrm{~g} \mathrm{~mL}^{-1}$ (serpentine) and centrifuged $2 \times 30 \mathrm{~min}$ at $2500 \mathrm{rpm}(1500 \mathrm{~g})$ in pre-weighed centrifuge tubes. After testing, the less dense solution was used for serpentine soil because at $2.0 \mathrm{~g} \mathrm{~mL}^{-1}$ some small serpentine mineral material was visible in the light fraction. Density was adjusted until the two soils presented similar (and very low) amounts of visible mineral material in the light fractions. Between centrifuge runs, floating (light fraction) material was pipetted onto pre-weighed nylon membrane filters in Nalgene filtration units and the pellet was resuspended. Filters were rinsed with $200 \mathrm{~mL}$ deionized water, oven-dried $24 \mathrm{~h}$ at $80^{\circ} \mathrm{C}$, and reweighed. Dense fraction material remained in the pellet, which was rinsed in $50 \mathrm{~mL}$ deionized water by repeated centrifuging $(4 \times 5 \mathrm{~min}, 1500 \mathrm{~g})$ then oven-dried $72 \mathrm{~h}$ at $80^{\circ} \mathrm{C}$ in the centrifuge tubes and weighed. Light fractions were ground by hand; dense fractions and whole (unfractionated) soil samples were ground with steel rods in capped plastic vials on a roller bar grinder.

Subsamples of sieved soil were weighed into tin capsules and combusted in a Carlo-Erba $\mathrm{C}: \mathrm{N}: \mathrm{S}$ analyzer coupled to a mass spectrometer for $\% \mathrm{C}$ and $\delta^{13} \mathrm{C}$ values. The $\mathrm{C}$ and $\mathrm{N}$ concentration was also measured by elemental analyzer at University of California, Berkeley.

Radiocarbon content was determined for 12 samples, each a composite of the 10 replicate plots for each soil (sandstone and serpentine), depth (two depths for the sandstone soil and one depth in the shallow serpentine soil), treatment 
(control and elevated $\mathrm{CO}_{2}$ ), and fraction (light and dense) combination. The low variation in soil $\delta^{13} \mathrm{C}$ among the treatment replicates (Table 2) showed that the amount of carbon from elevated $\mathrm{CO}_{2}$ inputs in each $\mathrm{SOM}$ fraction was relatively uniform. The graphite targets were prepared by oxidizing SOM to $\mathrm{CO}_{2}$ by sealed-tube combustion with cupric oxide followed by reduction of the cryogenically purified $\mathrm{CO}_{2}$ to graphite by hydrogen or zinc reduction (Vogel, 1992). Samples were analyzed by accelerator mass spectrometry at Lawrence Livermore National Laboratory. Analytical precision was reported to be $\pm 4-8 \%$. The $\Delta^{14} \mathrm{C}$ unit is normalized such that for the pre-1950 atmosphere, $\Delta^{14} \mathrm{C}=0 \%$ o (Stuiver and Polach, 1977). Positive values of $\Delta{ }^{14} \mathrm{C}$ indicate the presence of bomb-produced ${ }^{14} \mathrm{C}$, and samples with no ${ }^{14} \mathrm{C}$ have $\Delta^{14} \mathrm{C}=-1000 \%$ (half-life $=5730 \mathrm{yr}$ ). The calculation of fraction modern or $\Delta$ from the sample activity uses sample ${ }^{13} \mathrm{C}$ to correct for mass-dependent isotope fractionation. However, because the $\delta^{13} \mathrm{C}$ of the sample is not an appropriate measure of isotopic fractionation in elevated $\mathrm{CO}_{2}$ treatments, sample ${ }^{14} \mathrm{C}$ activity was corrected for isotopic fractionation following the procedure proposed by Torn and Southon (2001).

\subsection{Modeling soil carbon turnover in density fractions}

The turnover calculations presented here depend on three assumptions: (i) carbon cycling in the control plots (and the elevated $\mathrm{CO}_{2}$ plots before the experiment started in 1992) is in steady state, (ii) atmospheric $\delta^{13} \mathrm{C}$ values are effectively constant over the duration of the experiment, and (iii) the elevated $\mathrm{CO}_{2}$ treatment did not significantly alter the turnover time of the carbon pools in each fraction. We ran our models for the elevated $\mathrm{CO}_{2}$ treatment under both steady-state (i.e., no change in plant carbon inputs during 1992-1997) and non-steady-state (i.e., increase in inputs during 19921997) conditions. The goal of the turnover modeling is to divide each SOM density fraction into two functional pools and to come up with turnover times such that the predicted soil fraction ${ }^{14} \mathrm{C}$ and ${ }^{13} \mathrm{C}$ most closely match the measured values. We iteratively changed the (i) relative proportions of fast- versus slow-cycling carbon pools within a density fraction (before the $\mathrm{CO}_{2}$ treatment started in 1992), and (ii) the turnover times of the fast- and slow-cycling carbon pools of that density fraction until they matched the ${ }^{14} \mathrm{C}$ observed in the control soil and the ${ }^{13} \mathrm{C}$ and the ${ }^{14} \mathrm{C}$ values measured in the soil from the elevated $\mathrm{CO}_{2}$ treatment. We modeled each density fraction independently.

\subsubsection{One-pool and two-pool models}

To compare the results of turnover calculations that assume one or two pools per fraction, we estimated the turnover times of organic carbon in the density fractions using the same time-dependent, steady-state equations with either one pool or two pools. In both approaches, we assume each pool represents a well-mixed, homogeneous carbon pool where all organic compounds have equal probability of turnover (loss due to decomposition). For the one-pool model, each density fraction is a single pool. For the two-pool case, the model predicts the ${ }^{14} \mathrm{C}$ and ${ }^{13} \mathrm{C}$ value for each pool and the proportion, $p$, of carbon in each pool. Then the predicted fractiontotal ${ }^{14} \mathrm{C}$ and ${ }^{13} \mathrm{C}$ were compared with the measured isotopic composition of the fraction, where the fraction-total isotopic value was calculated as the mass-weighted average of the two pools as shown here for ${ }^{13} \mathrm{C}$ :

$p_{\text {fast }}+p_{\text {slow }}=1 \Rightarrow p_{\text {fast }}=1-p_{\text {slow }}$

$$
\begin{aligned}
\mathrm{C}_{t} \delta_{t} & =\mathrm{C}_{\text {slow }} \delta_{\text {slow }}+\mathrm{C}_{\text {fast }} \delta_{\text {fast }} \\
& \Rightarrow \delta_{t}=\frac{\mathrm{C}_{\text {slow }}}{\mathrm{C}_{t}} \delta_{\text {slow }}+\frac{\mathrm{C}_{\text {fast }}}{\mathrm{C}_{t}} \delta_{\text {fast }} \\
& \Rightarrow \delta_{t}=p_{\text {slow }} \delta_{\text {slow }}+p_{\text {fast }} \delta_{\text {fast }}
\end{aligned}
$$

$\delta_{t}=p_{\text {slow }} \delta_{\text {slow }}+\left(1-p_{\text {slow }}\right) \delta_{\text {fast }}$,

where $p=$ proportion of carbon in each pool; $\mathrm{C}=$ carbon stock; $\delta=\delta^{13} \mathrm{C}$ value of soil; and subscripts are $t=$ total sample (LF or DF), fast = fast-cycling carbon pool, and slow $=$ slow-cycling carbon pool.

\subsubsection{Estimating turnover times}

For each density fraction, turnover time $(\tau)$ was determined such that the model prediction of $\Delta^{14} \mathrm{C}$ and/or $\delta^{13} \mathrm{C}$ values most closely matched the measured value for the respective density fraction. The model was solved using Eqs. (2) and (3).

The modeling started in the year 1900. Using the assumption of steady-state plant inputs yields an estimate of turnover time in 1900 that is independent of plant-input rate:

$R=\frac{1 / \tau}{(1 / \tau)+\lambda}$,

where $R=$ the fraction modern of radiocarbon (dimensionless). Yearly atmospheric radiocarbon values were based on the literature (Stuiver et al., 1998; Hua and Barbetti, 2004).

Turnover times were modified in an iterative process until the resulting $\Delta^{14} \mathrm{C}$ and/or $\delta^{13} \mathrm{C}$ values for the respective density fraction matched the observed values from Table 2 . To facilitate comparison of the one- and two-pool model results, we calculated the flux-weighted turnover time for the soil with two pools, $\tau_{\text {effective, }}$, where total soil $\mathrm{CO}_{2}$ flux from the whole soil is $\mathrm{C} / \tau_{\text {effective. }}$. This flux-weighted $\tau$ was calculated as

$\tau_{\text {effective }}=\frac{1}{\left(\frac{f_{\text {fast }}}{\tau_{\text {fast }}}\right)+\left(\frac{f_{\text {slow }}}{\tau_{\text {slow }}}\right)}$,

where $\tau_{\text {effective }}=$ flux-weighted turnover time, $\tau_{\text {fast }}=$ turnover time of fast pool, $\tau_{\text {slow }}=$ turnover time of slow pool, 
Table 1. Isotopic signature of ambient/tank air and plant inputs used in the model.

\begin{tabular}{|c|c|c|c|c|c|}
\hline Variable & $\begin{array}{l}\text { Model parame- } \\
\text { ter }\end{array}$ & $\delta^{13} \mathrm{C}(\% \circ)$ & $\Delta^{14} \mathrm{C}(\% \circ)$ & Source & Remarks \\
\hline $\begin{array}{l}\text { Ambient air }\left(\mathrm{CO}_{2} \text { in }\right. \\
\text { ambient atmosphere })\end{array}$ & Ambient air & -8 & $\begin{array}{l}\text { Decrease from } 136 \\
\text { (1992) to } 104(1997)\end{array}$ & $\begin{array}{l}\text { Hua and Barbetti (2004) } \\
\left.\text { (ambient air }{ }^{14} \mathrm{C}\right)\end{array}$ & $\begin{array}{l}\text { Year-specific } \Delta^{14} \mathrm{C} \text { values } \\
\text { used in the model. }\end{array}$ \\
\hline $\begin{array}{l}\text { Tank air }\left(\mathrm{CO}_{2} \text { added to }\right. \\
\left.\text { elevated } \mathrm{CO}_{2} \text { chambers }\right)\end{array}$ & Tank air & -35 & -1000 & $\begin{array}{l}\text { Jackson et al. (1994) } \\
\left(\text { tank air }{ }^{13} \mathrm{C}\right)\end{array}$ & \\
\hline $\begin{array}{l}\text { Chamber air }\left(\mathrm{CO}_{2} \text { within }\right. \\
\left.\text { elevated } \mathrm{CO}_{2} \text { chambers }\right)\end{array}$ & Chamber air & -20 & $\begin{array}{l}\text { Decrease from }-368 \\
(1992) \text { to }-386(1997)\end{array}$ & $\begin{array}{l}\text { Jackson et al. (1994) } \\
\left.\text { (chamber air }{ }^{13} \mathrm{C}\right)\end{array}$ & $\begin{array}{l}\text { For }{ }^{14} \mathrm{C} \text {, mass balance } \\
\text { using } f(0.444) \text { and } \Delta^{14} \mathrm{C} \\
\text { of ambient air and tank air }\end{array}$ \\
\hline $\begin{array}{l}\text { Proportion of tank air in } \\
\text { elevated } \mathrm{CO}_{2} \text { chambers }\end{array}$ & $\mathrm{f}=0.444$ & & & $\begin{array}{l}\text { Calculation by a } \\
\text { two-member mixing model }\end{array}$ & $\begin{array}{l}\text { Mass balance using } \delta^{13} \mathrm{C} \\
\text { of ambient air, tank air and } \\
\text { chamber air. }\end{array}$ \\
\hline $\begin{array}{l}\text { Air-plant discrimination } \\
\text { against the heavier isotope }\end{array}$ & $\begin{array}{l}\text { Ambient }=\Delta_{\mathrm{A}} \\
\text { Elevated }=\Delta_{\mathrm{E}}\end{array}$ & $\begin{array}{l}-20.6 \\
-21.6\end{array}$ & $\begin{array}{l}-41.2 \\
-43.2\end{array}$ & $\begin{array}{l}\text { Jackson et al. (1994) } \\
\left({ }^{13} \mathrm{C} \text { discrimination factor }\right)\end{array}$ & $\begin{array}{l}\text { Assume the }{ }^{14} \mathrm{C} \\
\text { discrimination is two times } \\
\text { the }{ }^{13} \mathrm{C} \text { discrimination. }\end{array}$ \\
\hline${ }^{13} \mathrm{C}$ and ${ }^{14} \mathrm{C}$ in plants & $\begin{array}{l}\text { Ambient }=\mathrm{P}_{\mathrm{C}} \\
\text { Elevated }=\mathrm{P}_{\mathrm{E}}\end{array}$ & $\begin{array}{l}-28.6 \\
-41.6\end{array}$ & $\begin{array}{l}\text { Same as the } \Delta^{14} \mathrm{C} \\
\text { value of the air inside } \\
\text { the chambers }\end{array}$ & & $\begin{array}{l}\text { For }{ }^{13} \mathrm{C}, P=\Delta+\text { air } \\
\text { For }{ }^{14} \mathrm{C}, \mathrm{P}=\text { air }\end{array}$ \\
\hline
\end{tabular}

$f_{\text {fast }}=$ weight fraction of fast pool, and $f_{\text {slow }}=$ weight fraction of slow pool.

Turnover calculations were based on the data, references, and calculation methods compiled in Table 1 . The proportion of fossil fuel air, $f(0.444)$, in the chamber air was calculated based on the measured ${ }^{13} \mathrm{C}$ values in the chamber air $(-20 \%)$, ambient air $(-8 \%)$, and tank air $(-35 \%)$. The ${ }^{14} \mathrm{C}$ content of $\mathrm{CO}_{2}$ in the chambers each year was estimated by mass balance, assuming 0.444 of the air was fossil fuel derived with $\Delta{ }^{14} \mathrm{C}=-1000 \%$ and $(1-0.444)$ was ambient air with $\Delta^{14} \mathrm{C}$ value of the Northern Hemisphere in that year.

\subsubsection{New carbon in each soil fraction}

The percentage of soil carbon derived from carbon fixed since the beginning of the experiment $\left(\% \mathrm{C}_{\text {new }}\right)$ was calculated following van Kessel et al. (2000):

$\% \mathrm{C}_{\text {new }}=\left(\frac{\delta^{13} \mathrm{C}_{\text {elevated-soil }}-\delta^{13} \mathrm{C}_{\text {ambient-soil }}}{\delta^{13} \mathrm{C}_{\text {elevated-plant }}-\delta^{13} \mathrm{C}_{\text {ambient-soil }}}\right) \times 100$,

where $\delta^{13} \mathrm{C}$ values for plant samples $\left(\delta^{13} C_{\text {elevated-plant }}\right)$ were taken from Jackson et al. (1994) and $\delta^{13} \mathrm{C}$ values for soil fraction samples $\left(\delta^{13} \mathrm{C}_{\text {elevated-soil }}\right.$ and $\left.\delta^{13} \mathrm{C}_{\text {ambient-soil }}\right)$ were measured directly.

\subsubsection{Quantifying the proportion of $\mathrm{CO}_{2}$ flux attributed to fast and slow pools}

The total annual carbon flux $\left(\mathrm{g} \mathrm{m}^{-2} \mathrm{yr}^{-1}\right)$ was calculated as the sum of the flux from the fast pool of the light fraction, the flux from the slow pool of the light fraction, the flux from the fast pool of the dense fraction, and the flux from the slow pool of the dense fraction:

$$
\begin{aligned}
\text { Flux } & =\frac{\mathrm{LF} \times p_{\text {fast, } \mathrm{LF}}}{\tau_{\text {fasat, } \mathrm{LF}}}+\frac{\mathrm{LF} \times p_{\text {slow }, \mathrm{LF}}}{\tau_{\text {slow, }}} \\
& +\frac{\mathrm{DF} \times p_{\text {fast }, \mathrm{DF}}}{\tau_{\text {fast, } \mathrm{DF}}}+\frac{\mathrm{DF} \times p_{\text {slow }, \mathrm{DF}}}{\tau_{\text {slow, } \mathrm{DF}}}
\end{aligned}
$$

where $\mathrm{LF}=$ light fraction $\left(\mathrm{g} \mathrm{m}^{-2}\right), \mathrm{DF}=$ dense fraction $\left(\mathrm{g} \mathrm{m}^{-2}\right), p=$ proportion of carbon in each fraction with fast or slow cycling rate, and $\tau$ is turnover time (years) of either fast- or slow-cycling carbon in either light or dense fraction.

The proportion of each density fraction in fast and slow pools was scaled by total soil carbon to estimate how much of the annual flux could be attributed to the amount of soil carbon that is turning over rapidly or slowly.

\subsection{Microbial biomass}

The chloroform fumigation-incubation method (Jenkinson and Powlson, 1976) was used to measure microbial biomass and to generate microbial-derived $\mathrm{CO}_{2}$ for isotopic analysis. Soil from $0-5 \mathrm{~cm}$ of sandstone grassland was collected in April 1996, and refrigerated until used, within five days of collection. This was nearly five growing seasons after the experiment began. The soil was sieved $(2 \mathrm{~mm})$ and macroscopic organic matter fragments like roots and leaves were removed. $15 \mathrm{~g}$ aliquots were moistened to $20 \%$ gravimetric moisture with distilled water and either incubated for 10 days (control) or fumigated with chloroform and then incubated for 10 days (fumigated). Three replicates of each treatment were incubated, but one of the jars from the elevated $\mathrm{CO}_{2}$ treatment leaked during incubation and one ${ }^{14} \mathrm{C}$ sample from the control treatment was lost on the vacuum line. 
Table 2. Mean carbon and nitrogen contents, $\mathrm{C}: \mathrm{N}$ ratio, isotopic values, and carbon stocks of two density fractions. Values in parentheses are standard error; $n=10$ except $\Delta^{14} \mathrm{C}$ is single value for composite of 10 samples.

\begin{tabular}{|c|c|c|c|c|c|c|c|c|c|c|c|c|}
\hline & \multicolumn{6}{|c|}{ Light fraction } & \multicolumn{6}{|c|}{ Dense fraction } \\
\hline & $\begin{array}{l}\mathrm{C} \\
\%\end{array}$ & $\begin{array}{l}\mathrm{N} \\
\%\end{array}$ & $\mathrm{C} / \mathrm{N}$ & $\begin{array}{r}\delta^{13} \mathrm{C} \\
\% \circ\end{array}$ & $\begin{array}{r}\Delta^{14} \mathrm{C} \\
\% \%\end{array}$ & $\begin{array}{r}\text { C-stock } \\
\mathrm{g} \mathrm{m}^{-2}\end{array}$ & $\begin{array}{l}\mathrm{C} \\
\%\end{array}$ & $\begin{array}{l}\mathrm{N} \\
\%\end{array}$ & $\mathrm{C} / \mathrm{N}$ & $\begin{array}{r}\delta^{13} \mathrm{C} \\
\% \circ\end{array}$ & $\begin{array}{r}\Delta^{14} \mathrm{C} \\
\% \%\end{array}$ & $\begin{array}{r}\text { C-stock } \\
\mathrm{g} \mathrm{m}^{-2}\end{array}$ \\
\hline \multicolumn{13}{|c|}{ Sandstone $0-15 \mathrm{~cm}$} \\
\hline Ambient & $15.2(0.59)$ & $0.90(0.03)$ & 16.8 & $-28.6(0.1)$ & 72 & $331(36)$ & $0.86(0.04)$ & $0.093(0.003)$ & 9.3 & $-27.5(0.1)$ & 11 & $1223(59)$ \\
\hline Elevated & $15.1(0.86)$ & $0.87(0.02)$ & 17.2 & $-32.7(0.4)$ & -92 & $354(35)$ & $0.92(0.03)$ & $0.099(0.003)$ & 9.4 & $-28.5(0.1)$ & -36 & $1156(73)$ \\
\hline$t$ test* & NS & NS & & $* *$ & & NS & NS & NS & & $* *$ & & NS \\
\hline \multicolumn{13}{|c|}{ Sandstone $15-30 \mathrm{~cm}$} \\
\hline Ambient & $17.9(2.14)$ & $0.93(0.05)$ & 19.0 & $-28.2(0.2)$ & -17 & $126(14)$ & $0.64(0.03)$ & $0.074(0.003)$ & 8.5 & $-26.7(0.1)$ & -65 & $922(30)$ \\
\hline Elevated & $16.1(1.04)$ & $0.88(0.05)$ & 18.3 & $-31.0(0.6)$ & -130 & $132(14)$ & $0.63(0.02)$ & $0.072(0.002)$ & 8.6 & $-27.0(0.2)$ & -111 & $941(44)$ \\
\hline$t$ test* & NS & NS & & $* *$ & & NS & NS & NS & & NS & & NS \\
\hline \multicolumn{13}{|c|}{ Serpentine $0-15 \mathrm{~cm}$} \\
\hline Ambient & $22.7(0.47)$ & $1.42(0.04)$ & 16.0 & $-28.8(0.1)$ & 61 & $395(46)$ & $1.46(0.07)$ & $0.156(0.005)$ & 9.3 & $-27.3(0.1)$ & -5 & $989(40)$ \\
\hline Elevated & $20.7(1.23)$ & $1.33(0.08)$ & 15.5 & $-33.7(0.3)$ & -80 & $370(29)$ & $1.36(0.06)$ & $0.152(0.007)$ & 8.9 & $-28.4(0.1)$ & -33 & $989(42)$ \\
\hline$t$ test* & NS & NS & & ** & & NS & NS & NS & & ** & & NS \\
\hline
\end{tabular}

* NS, not significant $(P<0.05)$; ${ }^{* *}$ significant $(P<0.05)$.

After incubation, the headspace gas was analyzed for $\mathrm{CO}_{2}$, ${ }^{13} \mathrm{C}$, and ${ }^{14} \mathrm{C}$ content. Samples for $\delta^{13} \mathrm{C}$ were removed with a gas-tight syringe and injected directly into a Finnigan GC mass spectrometer at Carnegie Institution for Science, Stanford. The ${ }^{14} \mathrm{C}$ samples were composited for analysis. For $\Delta^{14} \mathrm{C}, 1.5 \mathrm{mg}$ carbon was trapped by pumping headspace gas over a cryogenic trap. Samples were graphitized as above and $\Delta^{14} \mathrm{C}$ was measured by accelerator mass spectrometry at Lawrence Livermore National Laboratory. Headspace $\mathrm{CO}_{2}$ concentration was converted to mass using the ideal gas law at $T=293 \mathrm{~K}$ and $1 \mathrm{~atm}$ pressure. Microbial biomass $\mathrm{C}_{\mathrm{M}}$ was calculated as the difference in carbon respired in fumigated $\left(\mathrm{C}_{\mathrm{F}}\right)$ and control $\left(\mathrm{C}_{\mathrm{C}}\right)$ incubations divided by an extraction efficiency $k_{\mathrm{C}}$ (Jenkinson and Powlson, 1976).

The control (unfumigated) incubation gives an estimate of the isotopic values for heterotrophic respiration, although we do not expect it to be exactly the same as field values, because soil processing likely makes older carbon more bio-available. We estimated the isotopic composition of microbial biomass with a two-member mixing model, using the same assumptions that are in the microbial biomass calculation, namely that the amount of fumigated $\mathrm{CO}_{2}$ is equivalent to the amount of respired $\mathrm{CO}_{2}$ in the control incubation plus $\mathrm{CO}_{2}$ liberated from microbial biomass cells that were lysed by the chloroform.

$\mathrm{C}_{\mathrm{F}}=\mathrm{C}_{\mathrm{C}}+\mathrm{C}_{\mathrm{M}} k_{\mathrm{C}}$

$C_{\mathrm{F}} \delta_{\mathrm{F}}=C_{\mathrm{C}} \delta_{\mathrm{C}}+C_{\mathrm{M}} k_{\mathrm{C}} \delta_{\mathrm{M}}$

Equations (12) and (13) can be combined and simplified, yielding

$\delta_{\mathrm{M}}=\frac{C_{\mathrm{F}} \delta_{\mathrm{F}}-C_{\mathrm{C}} \delta_{\mathrm{C}}}{\mathrm{C}_{\mathrm{F}}-\mathrm{C}_{\mathrm{C}}}$, where $C_{\mathrm{M}}=$ microbial biomass carbon, $\mathrm{C}_{\mathrm{F}}=$ carbon respired in fumigated incubations, $\mathrm{C}_{C}=$ carbon respired in control incubations, $\delta_{\mathrm{M}}=$ isotopic value of biomass carbon, $\delta_{\mathrm{F}}=$ isotopic value of carbon respired in fumigated incubations, and $\delta_{\mathrm{C}}=$ isotopic value of carbon respired in control incubations.

We used the microbial biomass results in two ways: (1) to estimate the fraction of microbial biomass that was derived from pre-experiment (1992) photosynthesis; and (2) to estimate the fraction of heterotrophic respiration that was derived from pre-experiment photosynthesis. These calculations use a two-member mixing model, as shown above for soil carbon (Eq. 10).

\section{Results}

\subsection{New carbon in SOM fractions}

The fractionation procedure separated the soil into fractions with distinct $\mathrm{C}, \mathrm{N}$, and isotopic values (Table 2). Across soils and treatments, LF accounted for $12-29 \%$ of total soil carbon. The proportion of total horizon carbon in LF was twice as high in the $0-15 \mathrm{~cm}$ topsoil $(21-23 \%)$ as in the $15-30 \mathrm{~cm}$ depth $(12 \%)$ in the sandstone soil. Serpentine topsoils had a higher proportion of carbon in LF than did sandstone topsoils (27-29\% versus $21-23 \%$ ).

Compared to the DF, the LF was more carbon-rich, had a wider $\mathrm{C} / \mathrm{N}$ ratio, and, in the elevated $\mathrm{CO}_{2}$ plots, had incorporated more of the fossil fuel isotopic signature (Table 2). These results are consistent with the LF consisting of plant material in an early stage of decomposition that is on average cycling more quickly than is the DF. In complement, the low carbon concentration, narrow $\mathrm{C} / \mathrm{N}$ ratio, and old isotopic signature all indicate that the DF comprised more degraded material that was stabilized in association with soil minerals. 
The distinctive ${ }^{13} \mathrm{C}$ signature of plant inputs in the elevated $\mathrm{CO}_{2}$ treatment allowed us to determine the fraction of soil organic carbon derived from carbon photosynthesized after the experiment began (January 1992), hereafter called new carbon. Based on the incorporation of ${ }^{13} \mathrm{C}$, significantly more (by a factor of 3-5) new carbon had entered the LF than the DF (Table 4). The carbon in the LF was $21-36 \%$ new, while only $2-7 \%$ was new in any of the DF samples. This is consistent with the LF having faster turnover or at least having a larger pool of fast-cycling carbon than did the DF. There was more new carbon in the $0-15 \mathrm{~cm}$ depth than deeper in the sandstone soil (30\% versus $21 \%$ ). Comparing surface horizons between soil types, there was more new carbon in the serpentine topsoil than in the sandstone topsoil (36\% versus $30 \%)$.

\subsection{Soil carbon turnover times}

The turnover time estimates for the one-pool and two-pool models are summarized in Tables 3 and 4, respectively.

Using a one-pool model (Table 3 ), soil ${ }^{14} \mathrm{C}$ values in the control treatment yielded turnover times of DF (268-735 yr) roughly double those of LF (119-398 yr). In the elevated $\mathrm{CO}_{2}$ treatment and assuming steady-state conditions, soil ${ }^{13} \mathrm{C}$ values resulted in decadal turnover for $\mathrm{LF}(13-30 \mathrm{yr})$ and centennial turnover for DF $(155-800 \mathrm{yr})$, while soil ${ }^{14} \mathrm{C}$ values did not isolate a unique solution for turnover time of either fraction (low and high estimates were roughly 10 and $400-1300 \mathrm{yr}$ for a given sample). Assuming non-steady-state conditions for the elevated $\mathrm{CO}_{2}$ treatment due to increased plant productivity, the modeled turnover times were similar or slightly longer than those assuming a steady state, and the carbon pools of each fraction increased by up to $18 \%$ in 1997 compared to the pre-experiment year 1991 or to the control. It is important to note that the one-pool model can never match both measured ${ }^{14} \mathrm{C}$ and ${ }^{13} \mathrm{C}$ data in elevated $\mathrm{CO}_{2}$ treatment simultaneously. This result suggests that soil density fractions are not a homogenous pool and the one-pool model is missing important dynamics of the system.

We also applied the two-pool model to the control and elevated $\mathrm{CO}_{2}$ treatments, and as above assumed that both treatments have identical turnover times (Table 4), for steadystate and non-steady-state (for the elevated $\mathrm{CO}_{2}$ treatment) conditions. In contrast to the one-pool model, the two-pool model could fit all three isotopic data sets (control treatment ${ }^{14} \mathrm{C}$ and elevated $\mathrm{CO}_{2}$ treatment ${ }^{14} \mathrm{C}$ and ${ }^{13} \mathrm{C}$, Table 2). Therefore, we use the two-pool model from combined control and elevated $\mathrm{CO}_{2}$ treatments in the following results and discussion. Three broad trends are shown. First, the light fractions turn over more quickly than do the dense fractions. Second, ecosystem carbon residence times increased with depth for both light and dense fractions in all but one soil/depth/fraction case. Third, turnover time in the serpentine soil is slower than that in the sandstone soil, for each comparable density fraction and soil depth.
The results are similar between steady state and nonsteady state except that the turnover times of the fast pools in both LF and DF are slightly longer under non-steady-state conditions (Table 4). Hereafter, we refer to steady-state results except where noted. The LF in the sandstone soil (both depths) consisted of 21-30\% fast-cycling carbon with approximately $2 \mathrm{yr}$ turnover time. The amount and residence time of this fast-cycling component was similar across the two depths. The turnover time of the slow-cycling component of LF, however, was $\sim 4$ times slower in the $15-30 \mathrm{~cm}$ increment than at the surface (650 versus $150 \mathrm{yr}$ ). Thus, 70 $79 \%$ of the sandstone LF carbon cycles very slowly and has a turnover time that is influenced by depth. Moreover, in the serpentine soil, the best-fit model showed that a greater proportion of the LF (54\%) was fast cycling with a slower turnover time relative to sandstone LF ( $9 \mathrm{yr}$ ), and a smaller proportion of the LF (46\%) was slow cycling with a slower turnover time $(780 \mathrm{yr})$ than in the sandstone soil at same depth $(0-15 \mathrm{~cm})$. Therefore, the flux-weighted turnover time of the serpentine soil LF was a little slower $(16 \mathrm{yr})$ than that of the sandstone soil LF (5-9 yr).

The $\% \mathrm{C}_{\text {new }}$ for the serpentine soil LF (36\%) was less than the $\% \mathrm{C}_{\text {fast }}(54 \%)$, mainly because, with turnover time of $9 \mathrm{yr}$, not all the carbon in the fast-cycling pool had been turned over (replaced by new C) after 6 yr of experiment. These results validate a modeling approach of treating the LF as a combination of active and intermediate cycling carbon with turnover times that differ by an order of magnitude.

Although the mineral-associated DF is typically considered to comprise all slow-cycling $\mathrm{C}$, the DF data better fit a model with one significantly faster-cycling pool. The DF of sandstone and serpentine soils was $\sim 7 \%$ fast-cycling carbon with turnover times (2-8yr) similar to those of the LF fast-cycling pool (2-9 yr) from the same soil. In contrast, the more stable pool of the DF of sandstone soil cycled much more slowly than did its LF counterpart (300-880 versus $150-650 \mathrm{yr}$ for DF and LF, respectively), and more slowly with depth (150-300 versus $650-880$ yr for $0-15$ and $15-$ $30 \mathrm{~cm}$, respectively).

\subsection{Microbial biomass}

The isotopic signatures of microbial biomass carbon and biomass respiration of the sandstone topsoil $(0-5 \mathrm{~cm})$ are given in Table 5. Further calculations using two-member mixing models showed that nearly half the microbial biomass carbon was more than $5 \mathrm{yr}$ old (the experiment started in January 1992 and the soil was sampled in April 1996) and approximately $40 \%$ of the carbon respired by microbes (as measured in the unfumigated control treatment) had been fixed more than $5 \mathrm{yr}$ ago. Similar results were obtained from soil samples collected in 1997 (data not shown). 
Table 3. Turnover time ( $\tau$, year) modeling results for the one-pool model, in other words treating the LF (light fraction) carbon or DF (dense fraction) carbon as having one normally distributed turnover time. Column header shows the data set used to constrain turnover time. There are two solutions for the modeling of the observed ${ }^{14} \mathrm{C}$ value in elevated $\mathrm{CO}_{2}$ plots, hence two columns. For non-steady-state conditions, plant inputs increased by $37 \%$ in sandstone soils and by $25 \%$ in serpentine soils in the elevated $\mathrm{CO}_{2}$ experiment during the experimental period 1992-1997.

\begin{tabular}{|c|c|c|c|c|}
\hline & $\begin{array}{r}\text { Ambient } \mathrm{CO}_{2} \\
{ }^{14} \mathrm{C}\end{array}$ & $\begin{array}{c}\text { Elevated } \mathrm{CO}_{2} \\
{ }^{14} \mathrm{C} \text {, low value }\end{array}$ & $\begin{array}{r}\text { Elevated } \mathrm{CO}_{2} \\
{ }^{14} \mathrm{C} \text {, high value }\end{array}$ & $\begin{array}{r}\text { Elevated } \mathrm{CO}_{2} \\
{ }^{13} \mathrm{C}\end{array}$ \\
\hline \multicolumn{5}{|l|}{ Steady-state conditions } \\
\hline LF sandstone $0-15 \mathrm{~cm}$ & 119 & 8.5 & 930 & 17 \\
\hline LF sandstone $15-30 \mathrm{~cm}$ & 398 & 7.4 & 1313 & 30 \\
\hline LF serpentine $0-15 \mathrm{~cm}$ & 136 & 8.9 & 827 & 13 \\
\hline DF sandstone $0-15 \mathrm{~cm}$ & 268 & 11 & 473 & 155 \\
\hline DF sandstone $15-30 \mathrm{~cm}$ & 735 & 7.9 & 1115 & 800 \\
\hline DF serpentine $0-15 \mathrm{~cm}$ & 339 & 11 & 455 & 155 \\
\hline \multicolumn{5}{|c|}{ Non-steady-state conditions } \\
\hline LF sandstone $0-15 \mathrm{~cm}$ & & $11(16 \%)^{*}$ & $920(0.2 \%)^{*}$ & $21(9.4 \%)^{*}$ \\
\hline LF sandstone $15-30 \mathrm{~cm}$ & & $10(18 \%)$ & $1305(0.2 \%)$ & $39(5.3 \%)$ \\
\hline LF serpentine $0-15 \mathrm{~cm}$ & & $11(11 \%)$ & $820(0.2 \%)$ & $15(8.5 \%)$ \\
\hline DF sandstone $0-15 \mathrm{~cm}$ & & $14(13 \%)$ & $459(0.5 \%)$ & $180(1.2 \%)$ \\
\hline DF sandstone $15-30 \mathrm{~cm}$ & & $10(17 \%)$ & $1108(0.2 \%)$ & $820(0.3 \%)$ \\
\hline DF serpentine $0-15 \mathrm{~cm}$ & & $13(10 \%)$ & $445(0.3 \%)$ & $170(0.9 \%)$ \\
\hline
\end{tabular}

* Numbers in bracket are percent increase in soil carbon pool from pre-experiment years (before 1992) to 1997 as a result of increased plant inputs in the elevated $\mathrm{CO}_{2}$ treatment.

Table 4. Turnover time ( $\tau$, year) and its relative size (\% of total carbon) for light (LF) and dense (DF) density fractions. The data and constraints are for both ambient and elevated $\mathrm{CO}_{2}$ treatments modeled simultaneously with same turnover times, three constraints, ${ }^{14} \mathrm{C}_{\mathrm{ambient}}$, ${ }^{14} \mathrm{C}_{\text {elevated }}$, and ${ }^{13} \mathrm{C}_{\text {elevated. }} \mathrm{C}_{\text {new }}$ is based on ${ }^{13} \mathrm{C}$ signatures of plant inputs and soils and calculated by Eq. (10). For non-steady-state conditions, plant inputs increased by $37 \%$ in sandstone soils and by $25 \%$ in serpentine soils in the elevated $\mathrm{CO}_{2}$ experiment during the experimental period 1992-1997.

\begin{tabular}{|c|c|c|c|c|c|c|}
\hline & $\mathrm{C}_{\text {new }}(\%)$ & $\mathrm{C}_{\text {fast }}(\%)^{*}$ & $\tau_{\text {fast }}(\mathrm{yr})$ & $\tau_{\text {slow }}(\mathrm{yr})$ & $\tau_{\text {effective }}(\mathrm{yr})$ & $\begin{array}{r}\text { Pool increase } \\
(\%)^{* *}\end{array}$ \\
\hline \multicolumn{7}{|l|}{ Steady-state conditions } \\
\hline LF sandstone $0-15 \mathrm{~cm}$ & 30 & 30 & 1.6 & 150 & 5.2 & \\
\hline LF sandstone $15-30 \mathrm{~cm}$ & 21 & 21 & 2.0 & 650 & 9.4 & \\
\hline LF serpentine $0-15 \mathrm{~cm}$ & 36 & 54 & 8.8 & 780 & 16.1 & \\
\hline DF sandstone $0-15 \mathrm{~cm}$ & 7 & 7 & 1.6 & 300 & 21.3 & \\
\hline DF sandstone $15-30 \mathrm{~cm}$ & 2 & 8 & 2.0 & 880 & 24.4 & \\
\hline DF serpentine $0-15 \mathrm{~cm}$ & 7 & 7 & 8.2 & 410 & 92.6 & \\
\hline \multicolumn{7}{|c|}{ Non-steady-state conditions } \\
\hline LF sandstone $0-15 \mathrm{~cm}$ & 30 & $30 / 35.5$ & 4.0 & 150 & 12.6 & 10.1 \\
\hline LF sandstone $15-30 \mathrm{~cm}$ & 21 & $21 / 26.0$ & 3.4 & 650 & 15.9 & 7.1 \\
\hline LF serpentine $0-15 \mathrm{~cm}$ & 36 & $54 / 56.7$ & 10.0 & 780 & 18.3 & 6.4 \\
\hline DF sandstone $0-15 \mathrm{~cm}$ & 7 & $7 / 8.8$ & 4.2 & 300 & 50.6 & 2.8 \\
\hline DF sandstone $15-30 \mathrm{~cm}$ & 2 & $8 / 10.2$ & 3.7 & 880 & 44.1 & 2.7 \\
\hline DF serpentine $0-15 \mathrm{~cm}$ & 7 & $7 / 7.8$ & 9.5 & 410 & 103.8 & 1.2 \\
\hline
\end{tabular}

* Under non-steady-state conditions, $\mathrm{C}_{\text {fast }}(\%)$ increased from pre-experiment years (before 1992) to 1997 due to the faster incorporation of increased plant inputs to the fast-cycling component. ${ }^{* *}$ Percent increase in soil carbon pool from pre-experiment years (before 1992) to 1997 due to increased plant inputs in the elevated $\mathrm{CO}_{2}$ treatment. 


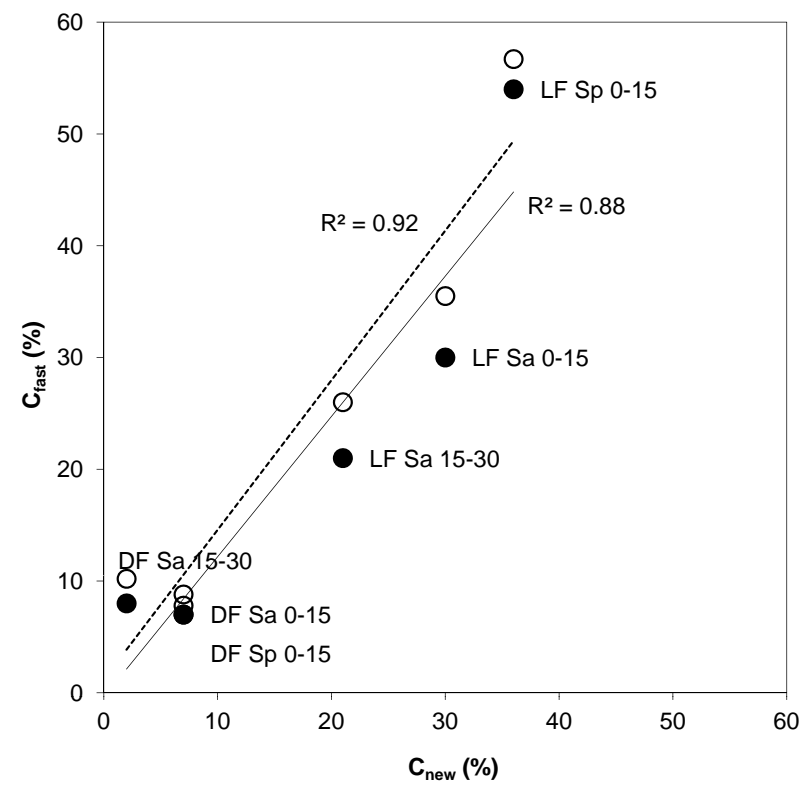

Fig. 2. The percentage of each soil fraction that is new (carbon incorporated since the experiment began; $\mathrm{C}_{n e w}$ ) versus the percentage of each soil fraction that is fast cycling $\left(\mathrm{C}_{\mathrm{fast}}\right)$ in 1997 . The value of $\mathrm{C}_{\text {new }}$ is independent of the steady-state assumption because it was calculated directly from the soil $\delta^{13} \mathrm{C}$ value. $\mathrm{C}_{\text {new }}$ explains 88 and $92 \%$ of the variation in $\mathrm{C}_{\text {fast }}$ under steady-state conditions and non-steady-state conditions, respectively $(n=6, P<0.01$ for each case). Legend: LF, light fraction; DF, dense fraction; Sa, sandstone; $\mathrm{Sp}$, serpentine. Filled circles and solid line represent steady-state conditions. Open circles (dashed line) represent non-steady-state conditions; the open circle is right above the filled circle for the same fraction/soil/depth combination.

\section{Discussion}

\subsection{New carbon in SOM fractions}

In this study, the percentage of each soil physical fraction that was fast cycling $\left(\% \mathrm{C}_{\text {fast }}\right)$ was close to the value for the $\% \mathrm{C}_{\text {new }}$ in that fraction. Considering all 6 soil type/depth/fraction cases, $\% \mathrm{C}_{\text {new }}$ explained $88 \%$ or $92 \%$ of the variability in $\% \mathrm{C}_{\text {fast }}$ in the elevated $\mathrm{CO}_{2}$ treatment $(P<0.01$, Fig. 2$)$. More generally, the two values $\left(\% \mathrm{C}_{\text {new }}\right.$ and $\% \mathrm{C}_{\text {fast }}$; Table 4) will be almost equivalent if (1) the duration of the experiment is longer than the turnover time of the fast pool, so that enough of the fast pool has turned over to new carbon; and (2) the turnover time of the slow pool is much longer than the duration of the experiment, so that very little of the slow pool will have accumulated new carbon. Under these conditions, $\% \mathrm{C}_{\text {new }}$ could be used as an easy method for estimating the minimum value of $\%$ fast cycling even in conditions where it is not possible or affordable to model two pools explicitly.

\subsection{Turnover times}

The two-pool model gave a better and more robust fit to the data than did the one-pool model. Moreover, the twopool model results did not differ significantly between nonsteady-state conditions (for the elevated $\mathrm{CO}_{2}$ treatment) and steady-state conditions (Table 4).

For all three soil type/depth cases, the turnover time of the fast pool was nearly the same in the light and dense fractions, while turnover of the slow pool was 1.4-2 times slower in the DF than in the LF except the serpentine soil (Table 4). This may be because the fast-cycling pool has similar organic matter chemistry in light and dense fractions, while the slow-cycling pool has different organic matter chemistry or physico-chemical stabilization between the two physical fractions.

Additionally, the turnover time of the fast-cycling pool (in LF or DF) did not change substantially with depth, while the turnover time of the slow-cycling pool increased 3-4 times when going from surface $(0-15 \mathrm{~cm})$ to the next horizon $(15-30 \mathrm{~cm})$ in sandstone grassland. One possible explanation is that, relative to the fast-cycling carbon, the turnover time of the slow-cycling material is dominantly influenced by physico-chemical stabilization that increases with depth (Rumpel and Kögel-Knabner, 2011).

Even though the plots shared the same climate and similar plant species composition, the soil carbon turnover and fast/slow pool partitioning was different in serpentine grassland than in sandstone grassland, with a slower overall turnover time $\left(\tau_{\text {effective }}\right)$ for serpentine. There are many potentially relevant differences between the two soils; the serpentine grassland has lower productivity, lower plant biomass, different soil mineralogy and cation composition, and shallower soils such that the $0-15 \mathrm{~cm}$ layer is much closer to bedrock than for the sandstone grassland (Hungate et al., 1997). Although serpentine soils are uncommon, they can be easily paired with other soils with the same climate and plant communities, and thus they could provide an interesting natural experiment to explore the role of soil mineralogy on decomposition (Torn et al., 1997; Rasmussen et al., 2005).

We showed that it is practical to partition soil physical fractions into multiple pools using a dual isotopic label, such as that provided by most elevated $\mathrm{CO}_{2}$ experiments. A spreadsheet model for fitting two pools simultaneously is only slightly more complicated than that for fitting one pool to the data. An alternative method to partitioning the fractions is to use a single isotope over multiple time points, such as ${ }^{13} \mathrm{C}$ in soil from an elevated $\mathrm{CO}_{2}$ experiment (van Kessel et al., 2000) or under $\mathrm{C}_{3}-\mathrm{C}_{4}$ vegetation change (Balesdent et al., 1988). However, the use of ${ }^{14} \mathrm{C}$ allowed modeling of the control soil as well, which is not possible when only using ${ }^{13} \mathrm{C}$.

The pattern in turnover times confirms earlier suggestions that fractionation of soil into light and dense fractions 
Table 5. Isotopic signatures of microbial biomass and biomass respiration measured for the sandstone topsoil (0-5 cm) in April 1996 .

\begin{tabular}{|c|c|c|c|c|c|c|}
\hline Variable & $\begin{array}{l}\text { Model } \\
\text { parameter* }\end{array}$ & $\begin{array}{l}\delta^{13} \mathrm{C} \\
(\% \circ)\end{array}$ & $\begin{array}{l}\Delta^{14} \mathrm{C} \\
(\% \circ)\end{array}$ & $\begin{array}{l}\text { Fraction } \\
\text { modern }\end{array}$ & Source & Remarks \\
\hline $\begin{array}{l}\mathrm{CO}_{2} \text { respired during } \\
\text { 10-day incubation from } \\
\text { fumigated treatment }\end{array}$ & $\begin{array}{l}\text { Ambient }=F_{\mathrm{A}} \\
\text { Elevated }=F_{\mathrm{E}}\end{array}$ & $\begin{array}{l}-28 \\
-35\end{array}$ & $\begin{array}{l}135 \\
-183\end{array}$ & $\begin{array}{l}1.135 \\
0.817\end{array}$ & Measured & Direct measurement \\
\hline $\begin{array}{l}\mathrm{CO}_{2} \text { respired during } \\
\text { 10-day incubation from } \\
\text { unfumigated treatment }\end{array}$ & $\begin{array}{l}\text { Ambient }=C_{\mathrm{A}} \\
\text { Elevated }=C_{\mathrm{E}}\end{array}$ & $\begin{array}{l}-29 \\
-37\end{array}$ & $\begin{array}{l}125 \\
-213\end{array}$ & $\begin{array}{l}1.125 \\
0.787\end{array}$ & Measured & Direct measurement \\
\hline Microbial biomass & $\begin{array}{l}\text { Ambient }=M_{\mathrm{A}} \\
\text { Elevated }=M_{\mathrm{E}}\end{array}$ & $\begin{array}{l}-27 \\
-34\end{array}$ & $\begin{array}{l}140 \\
-162\end{array}$ & $\begin{array}{l}1.140 \\
0.838\end{array}$ & Eqs. (12), (13), (14) & $\begin{array}{l}\text { Mass balance using } \\
\mathrm{CO}_{2} \text { respired from } \\
\text { fumigated and } \\
\text { unfumigated treatments }\end{array}$ \\
\hline
\end{tabular}
${ }^{*} F, C$, and $M$ stand for fumigated, unfumigated (control), and microbial biomass, respectively. Subscript letters $\mathrm{A}$ and $\mathrm{E}$ represent ambient and elevated $\mathrm{CO}_{2}$
treatment, respectively.

does not physically separate soil into homogeneous pools (Trumbore et al., 1989; Trumbore and Zheng, 1996). Even the mineral-associated dense fraction contains a range of turnover times (Trumbore, 2000), as sequential density fractionations have confirmed. But none of the sequential density fractionation studies (e.g., Sollins et al., 2006, 2009) or comparisons of free and occluded light fraction (e.g., Rasmussen et al., 2005; McFarlane et al., 2013) has isolated the fast-cycling component of the dense or light fractions, respectively. A contribution of our work relative to these previous studies is the mathematical estimation of a small but very dynamic component of each density fraction.

The highly dynamic carbon pool has important biogeochemical implications. Having a small, very fast-cycling pool of carbon means that a small fraction of total soil carbon is responsible for most of the $\mathrm{CO}_{2}$ efflux. Taking into account the carbon content and turnover time of each pool as well as the carbon content of the whole soil profile (Tables 2 and 4), in the sandstone soil, $11 \%$ of soil carbon contributes more than $90 \%$ of the annual $\mathrm{CO}_{2}$ efflux. This shows that only about $10 \%$ of the soil carbon stock could be lost rapidly, on the order of years, to environmental change such as elevated temperature or decreasing plant inputs. Conversely, about $90 \%$ of the soil carbon is not dynamic on fast timescales. It has been established that studies using one pool per soil profile (Raich and Schlesinger, 1992; Giardina and Ryan, 2000) greatly overestimate the amount of moderately responsive carbon in the soil, while missing the small, most dynamic fraction (Trumbore, 2000). We find that even treating each physical fraction as a single pool - such as we and others have done in previous work (e.g., Rasmussen et al., 2005, Mikutta et al., 2006; Bird et al., 2008; McFarlane et al., 2013) - underestimates the near-term response of soil, and in the long term overestimates the size of the carbon pool that is involved in decadal scale fluxes. Isolating fractions, and mod- eling each fraction as a single pool, is still a large improvement over treating all soil carbon as one pool and is representative of the turnover time of most of the carbon in the sample, but it should be recognized that a small fraction of this mass accounts for most of the $\mathrm{CO}_{2}$ flux and the dynamics.

Figure 3 compares the effect of assuming that soil carbon comprises one versus two pools on predictions of the longterm response to changes in decay rate (Fig. 3a) or plant inputs (Fig. 3B). Both assumptions (one versus two pools) result in the same stock at a new equilibrium, but with different response trajectories. The initial, sharp drop in soil carbon stock with doubling decay rate in the two-pool case (Fig. 3a) occurs because the fast pool approaches a new equilibrium stock within a few years. Subsequently, the slow pool has a very slow response time and it takes about $300 \mathrm{yr}$ for the whole fraction to reach the equilibrium stock. The single pool model has (by definition) an intermediate turnover time, and this allows for moderately rapid exponential decline in stock; it approaches the new equilibrium in about $30 \mathrm{yr}$ (Fig. 3a). In other words, the one-pool model overestimates the amount of carbon that can be lost from the soil and transferred to atmosphere in the decades after an environmental perturbation, as well as overestimating the amount of carbon that can be sequestered in the soil in the next few decades if carbon inputs (as NPP) to soil were increased (Fig. 3b). This example also helps to illustrate how equating the mean, ${ }^{14} \mathrm{C}$-derived age of SOM (a mass-weighted age of material in the soil) with SOM turnover time (i.e., the flux-weighted age of material leaving the soils) can create large errors in the predicted dynamics of soil organic matter, for example if even a small fraction is more ${ }^{14} \mathrm{C}$ depleted than the bulk material (i.e., giving the one-pool model a longer turnover time; Trumbore, 2009). 

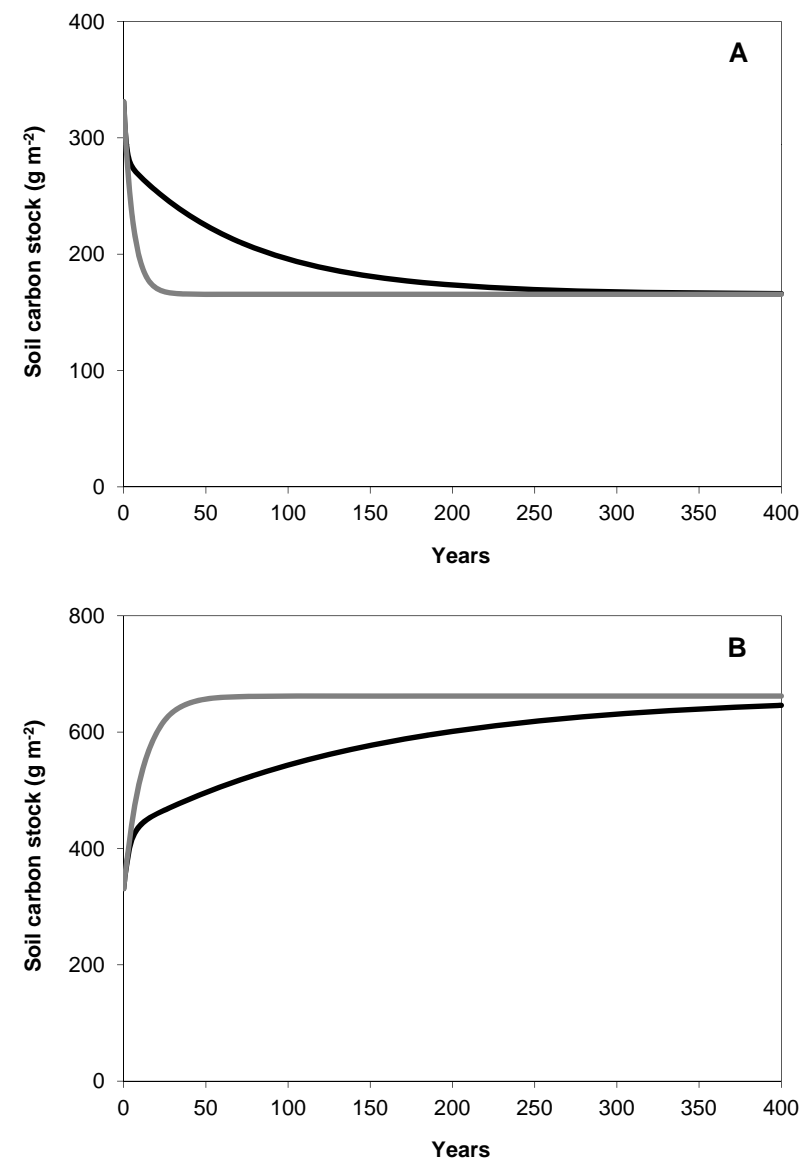

Fig. 3. Change in soil carbon stock $\left(\mathrm{g} \mathrm{m}^{-2}\right)$ after (A) doubling of decay rates (or $50 \%$ decrease in turnover times), and (B) doubling of NPP inputs for the two-pool (black line) and one-pool (grey line) models. For the two-pool model, the turnover time data are for sandstone $0-15 \mathrm{~cm}$ light fraction, in which $30 \%$ of the fraction has $\tau=4 \mathrm{yr}$ and $70 \%$ has $\tau=150 \mathrm{yr}$ (Table 4 ). The one-pool model has a single turnover time (12.6 yr) and gives the same total soil $\mathrm{CO}_{2}$ flux $\left(26.4 \mathrm{~g} \mathrm{~m}^{-2} \mathrm{yr}^{-1}\right)$ from a stock of $331 \mathrm{~g} \mathrm{~m}^{-2}$ in steady state as does the two-pool model.

\subsection{Microbial biomass}

The isotopic composition of microbial biomass and microbial-respired $\mathrm{CO}_{2}$ in the sandstone soil $(0-5 \mathrm{~cm})$ showed that nearly half the microbial biomass carbon was more than $5 \mathrm{yr}$ old and approximately $40 \%$ of the carbon respired by microbes had been fixed more than $5 \mathrm{yr}$ ago. Bulk microbial biomass could have an older isotopic signature if microbes consume older soil carbon, for example recycling microbial biomass, or if a significant fraction of the microbial biomass is dormant or otherwise turns over very slowly. Two earlier studies based on the ${ }^{14} \mathrm{C}$ value of microbial biomass or microbial-respired $\mathrm{CO}_{2}$ (Kramer and Gleixner, 2006; Garnett et al., 2011) also found microbial biomass contained old carbon and interpreted that a component of the soil microbial community used older soil carbon as substrates. However, in our study the isotopic results suggest that use of older substrates was unlikely the sole explanation for older microbial carbon - in other words, a mass balance of inputs and outputs suggests that it is unlikely that half the microbial biomass is supported by assimilating older soil carbon. Specifically, $90 \%$ of the microbial respiration came from only $10 \%$ of the total soil carbon (the fast pool, with young isotopic signature); for the assimilation associated with the remaining $10 \%$ of respired $\mathrm{CO}_{2}$ to support $50 \%$ of the biomass would require that microbes assimilating old carbon are at least five times as efficient in retaining assimilated carbon in biomass or turn over at least three times more slowly.

\subsection{Implications}

Recognizing that soil physical fractions are better described as comprising at least two functional pools of very different dynamics has three main mechanistic implications.

First, the light fraction does not contain all the easily decomposable organic matter in a soil sample, and is not itself all easily decomposable. Organic matter in the light fraction can be subject to different degrees of physical protection, as free and occluded (inter- and intra-aggregate particulate organic matter, respectively) light fraction materials have been shown to incorporate ${ }^{14} \mathrm{C}$ at different rates (Swanston et al., 2005). There is empirical evidence that there are chemically different kinds of organic carbon within the light fraction (Golchin et al., 1994). In addition to labile plant materials, occluded light fraction in forest, grassland, and arable soil contained more charred materials than the free light fraction (Brodowski et al., 2006). We offer as a hypothesis for a future study that for many soils there is a useful generalization that the light fraction comprises plant inputs in spectrum of decay (fast pool) and black carbon (slow pool).

Second, and perhaps even more important, the dense fraction contains both strongly bound (and old) and weakly associated, fast-cycling (and younger) organic matter. Similar conclusions were reached by sequential density fractionation combined with radiocarbon, near-edge X-ray absorption fine structure (NEXAFS), and thermal calorimetry (Kleber et al., 2011). This also confirms findings from coniferous forest soils, where acid hydrolysis separated the DF $\left(\Delta^{14} \mathrm{C}\right.$ value of $-1 \%$ ) into a decadal-cycling hydrolyzed fraction (74\% of DF C; $\Delta^{14} \mathrm{C}=+25 \%$ ) and slower-cycling non-hydrolyzable residue (26\% of DF C; $\Delta^{14} \mathrm{C}=-74 \%$; Trumbore and Zheng, 1996). Recent conceptual models for mineral-organic interactions are consistent with this observation. For example, Kleber et al. (2007) conceptualized SOM as having a heterogeneous range of amphiphilic properties, and capable of self-organization in a polar aqueous solution (water), suggesting that SOM sorbs to mineral surfaces with different exchange kinetics, including a component or outer layer that is only weakly stabilized.

Third, depth had little influence on turnover of the fast-cycling pool, but strongly affected turnover in the 
slow-cycling pool of both fractions. Increasing soil depth corresponds to differences in decomposition environment such as pore space, aggregation, and oxygen availability, such that the sum of protective mechanisms is higher with depth (Rumpel and Kögel-Knabner, 2011). We infer that the turnover time of the slow-cycling pool responds more to the protective environment than does the fast pool, likely because the mechanisms of stabilization are linked to the physical and chemical properties of the soil (von Lützow et al., 2006; Schmidt et al., 2011). In contrast, the finding that the turnover time of the fast pool was $2-9 \mathrm{yr}$ regardless of depth or density fraction is consistent with having organic matter chemistry as the main constraint on decomposition rates of that pool. However, the finding is equally consistent with the existence of hot spots of decomposition, which can occur for example because of heterogeneity in soil structure (Nunan et al., 2003; Chabbi et al., 2009), rhizosphere influence (Cheng et al., 2003; Kuzyakov, 2010), and microbial predation (Griffiths, 1994).

Significant and efficient sequestration of carbon in soil will require ways to transfer carbon into the slow pool (which is stabilized by protective mechanisms). An increase in productivity or decrease in respiration from the fast pool alone will not be as effective, because, for example, a $50 \%$ reduction in the decay constant for heterotrophic respiration would double the steady-state stock only of the small-sized fast pool, and leave the large slow-pool reservoir mostly unaffected.

Although the ideal SOM model might have a continuum of turnover times, there is a qualitative improvement in capturing SOM dynamics by moving from a one-pool model to a two-pool model for any component or physical fraction (three or more pools would be even better, but the biggest jump in predictive ability is between one and two pools). For process-level studies and carbon budgeting, it is worth the effort to look for situations that will allow constraining such a model. The most obvious opportunity is provided by elevated $\mathrm{CO}_{2}$ experiments using OTC or FACE (free-air $\mathrm{CO}_{2}$ enrichment) facilities. There have been 37 FACE experiments globally and more than 10 experiments are still running (http: //public.ornl.gov/face/global_face.shtml). Soils with the dual isotopic label from these and other experiments could be exploited to learn much more about the rates and controls of soil carbon cycling (e.g., Fontaine et al., 2007; Hopkins et al., 2012; O'Brien et al., 2013). In fact, it may be difficult to accurately capture the mechanisms of soil carbon stabilization or predict rates of carbon cycling without the ability to combine isotopic tracers with physical fractionations.

Acknowledgements. This work was supported by the Laboratory Directed Research and Development Program at Lawrence Berkeley National Laboratory, US Department of Energy under contract no. DE-AC03-76SF00098 and by the Office of Science, US Department of Energy under contract no. DE-AC02-05CH11231. The Jasper Ridge elevated $\mathrm{CO}_{2}$ experiment was supported by grants from the US National Science Foundation to the Carnegie
Institution for Science, Stanford University, and University of California, Berkeley. We thank two anonymous reviewers for their valuable comments that improved this manuscript.

Edited by: D. Obrist

\section{References}

Ågren, G. I. and Bosatta, E.: Theoretical analysis of long-term dynamics of carbon and nitrogen in soils, Ecology, 68, 1181-1189, 1987.

Amundson, R.: The carbon budget in soils, Annu. Rev. Earth Planet Sci., 29, 535-562, 2001

Balesdent, J., Wagner, G. H., and Mariotti, A.: Soil organic matter turnover in long-term field experiments as revealed by carbon-13, Soil Sci. Soc. Am. J., 52, 118-124, 1988.

Bird, J. A., Kleber, M., and Torn, M. S.: ${ }^{13} \mathrm{C}$ and ${ }^{15} \mathrm{~N}$ stabilization dynamics in soil organic matter fractions during needle and fine root decomposition, Org. Geochem., 39, 465-477, 2008.

Brodowski, S., John, B., Flessa, H., and Amelung, W.: Aggregateoccluded black carbon in soil, Eur. J. Soil Sci., 57, 539-546, 2006.

Cardon, Z. G., Hungate, B. A., Cambardella, C. A., Chapin, F. S., Field, C. B., Holland, E. A., and Mooney, H. A.: Contrasting effects of elevated $\mathrm{CO}_{2}$ on old and new soil carbon pools, Soil Biol. Biochem., 33, 365-373, 2001.

Chabbi, A., Kögel-Knabner, I., and Rumpel, C.: Stabilised carbon in subsoil horizons is located in spatially distinct parts of the soil profile, Soil Biol. Biochem., 41, 256-261, 2009.

Cheng, W. X., Johnson, D. W., and Fu, S. L.: Rhizosphere effects on decomposition: controls of plant species, phenology, and fertilization, Soil Sci. Soc. Am. J., 67, 1418-1427, 2003.

Christensen, B. T.: Physical fractionation of soil and structural and functional complexity in organic matter turnover, Eur. J. Soil Sci., 52, 345-353, 2001.

Crow, S. E., Swanston, C. W., Lajtha, K., Brooks, J. R., and Keirstead, H.: Density fractionation of forest soils: methodological questions and interpretation of incubation results and turnover time in an ecosystem context, Biogeochemistry, 85, 6990, 2007

Davidson, E. A., Trumbore, S. E., and Amundson, R.: Biogeochemistry: Soil warming and organic carbon content, Nature, 408, 789-790, 2000.

Derrien, D. and Amelung, W.: Computing the mean residence time of soil carbon fractions using stable carbon isotopes: impacts of the model frameworks, Eur. J. Soil Sci., 62, 237-252, 2011.

Dijkstra, P., Ishizu, A., Doucett, R., Hart, S. C., Schwartz, E., Menyailo, O. V., and Hungate, B. A.: ${ }^{13} \mathrm{C}$ and ${ }^{15} \mathrm{~N}$ natural abundance of the soil microbial biomass, Soil Biol. Biochem., 38, 3257-3266, 2006.

Field, C. B., Chapin, F. S., Chiariello, N. R., Holland, E. A., and Mooney, H. A.: The Jasper Ridge $\mathrm{CO}_{2}$ experiment: design and motivation, in: Carbon Dioxide and Terrestrial Ecosystems, edited by: Koch, G. W. and Mooney, H. A., Academic Press, San Diego, 121-145, 1996.

Fontaine, S., Barot, S., Barré, P., Bdioui, N., Mary, B., and Rumpel, C.: Stability of organic carbon in deep soil layers controlled by fresh carbon supply, Nature, 450, 277-280, 2007. 
Garnett, M. H., Bol, R., Bardgett, R. D., Wanek, W., Bäumler, R., and Richter, A.: Natural abundance radiocarbon in soil microbial biomass: Results from a glacial foreland, Soil Biol. Biochem., 43, 1356-1361, 2011.

Gaudinski, J. B., Trumbore, S. E., Davidson, E. A., and Zheng, S.: Soil carbon cycling in a temperate forest: radiocarbon-based estimates of residence times, sequestration rates and partitioning of fluxes, Biogeochemistry, 51, 33-69, 2000.

Giardina, C. P. and Ryan, M. G.: Evidence that decomposition rates of organic carbon in mineral soil do not vary with temperature, Nature, 404, 858-861, 2000.

Golchin, A., Oades, J. M., Skjemstad, J. O., and Clarke, P.: Study of free and occluded particulate organic matter in soils by solid state ${ }^{13} \mathrm{C}$ CP/MAS NMR Spectroscopy and Scanning Electron Microscopy, Aust. J. Soil Res., 32, 285-309, 1994.

Griffiths, B. S.: Microbial-feeding nematodes and protozoa in soil: Their effects on microbial activity and nitrogen mineralization in decomposition hotspots and the rhizosphere, Plant Soil, 164, 25-33, 1994.

Hopkins, F. M., Torn, M. S., and Trumbore, S. E.: Warming accelerates decomposition of decades-old carbon in forest soils, Proc. Natl. Acad. Sci. USA, 109, E1753-E1761, 2012.

Hua, Q. and Barbetti, M.: Review of tropospheric bomb ${ }^{14} \mathrm{C}$ data for carbon cycle modeling and age calibration purposes, Radiocarbon, 46, 1273-1298, 2004.

Hungate, B. A., Holland, E. A., Jackson, R. B., Chapin, F. S., Mooney, H. A., and Field, C. B.: The fate of carbon in grasslands under carbon dioxide enrichment, Nature, 388, 576-579, 1997.

Hungate, B. A., Jackson, R. B., Field, C. B., and Chapin, F. S.: Detecting changes in soil carbon in $\mathrm{CO}_{2}$ enrichment experiments, Plant Soil, 187, 135-145, 1996.

Jackson, R. B., Sala, O. E., Field, C. B., and Mooney, H. A.: $\mathrm{CO}_{2}$ alters water use, carbon gain, and yield for dominant species in a natural grassland, Oecologia, 98, 257-262, 1994.

Jenkinson, D. S. and Powlson, D. S.: The effects of biocidal treatments on metabolism in soil - V. A method for measuring soil biomass, Soil Biol. Biochem., 8, 209-213, 1976.

Jenkinson, D. S.: The turnover of organic carbon and nitrogen in soil, Philos. Trans. R. Soc. B-Biol. Sci., 329, 361-368, 1990.

Kandeler, E., Mosier, A. R., Morgan, J. A., Milchunas, D. G., King, J. Y., Rudolph, S., and Tscherko, D.: Response of soil microbial biomass and enzyme activities to the transient elevation of carbon dioxide in a semi-arid grassland, Soil Biol. Biochem., 38, 24482460, 2006.

Kleber, M., Nico, P. S., Plante, A., Filley, T., Kramer, M., Swanston, C., and Sollins, P.: Old and stable soil organic matter is not necessarily chemically recalcitrant: implications for modeling concepts and temperature sensitivity, Global Change Biol., 17, 1097-1107, 2011.

Kleber, M., Sollins, P., and Sutton, R.: A conceptual model of organo-mineral interactions in soils: self-assembly of organic molecular fragments into multilayered structures on mineral surfaces, Biogeochemistry, 85, 9-24, 2007.

Kramer, C. and Gleixner, G.: Variable use of plant- and soilderived carbon by microorganisms in agricultural soils, Soil Biol. Biochem., 38, 3267-3278, 2006.

Kuzyakov, Y.: Priming effects: Interactions between living and dead organic matter, Soil Biol. Biochem., 42, 1363-1371, 2010.
Marín-Spiotta, E., Swanston, C. W., Torn, M. S., Silver, W. L., and Burton, S. D.: Chemical and mineral control of soil carbon turnover in abandoned tropical pastures, Geoderma, 143, 49-62, 2008.

Masiello, C. A., Chadwick, O. A., Southon, J., Torn, M. S., and Harden, J. W.: Weathering controls on mechanisms of carbon storage in grassland soils, Glob. Biogeochem. Cycle, 18, GB4023, doi:10.1029/2004GB002219, 2004.

McFarlane, K. J., Torn, M. S., Hanson, P. J., Porras, R. C., Swanston, C. W., Callaham, M. A., and Guilderson, T. P., Comparison of soil organic matter dynamics at five temperate deciduous forests with physical fractionation and radiocarbon measurements, Biogeochemistry, 112, 457-476, 2013.

Mikutta, R., Kleber, M., Torn, M. S., and Jahn, R.: Stabilization of soil organic matter: association with minerals or chemical recalcitrance? Biogeochemistry, 77, 25-56, 2006.

Moni, C., Derrien, D., Hatton, P. J., Zeller, B., and Kleber, M.: Density fractions versus size separates: does physical fractionation isolate functional soil compartments?, Biogeosciences, 9, 51815197, 2012, http://www.biogeosciences.net/9/5181/2012/.

Nunan, N., Wu, K., Young, I. M., Crawford, J. W., and Ritz, K.: Spatial distribution of bacterial communities and their relationships with the micro-architecture of soil, FEMS Microbiol. Ecol., 44, 203-215, 2004.

O'Brien, S. L., Jastrow, J. D., McFarlane, K. J., Guilderson, T. P., and Gonzalez-Meler, M. A.: Decadal cycling within longlived carbon pools revealed by dual isotopic analysis of mineralassociated soil organic matter, Biogeochemistry, 112, 111-125, 2013.

Parton, W. J., Schimel, D. S., Cole, C. V., and Ojima, D. S.: Analysis of factors controlling soil organic matter levels in Great Plains grasslands, Soil Sci. Soc. Am. J., 51, 1173-1179, 1987.

Raich, J. W. and Schlesinger, W. H.: The global carbon-dioxide flux in soil respiration and its relationship to vegetation and climate, Tellus Ser. B-Chem. Phys. Meteorol., 44, 81-99, 1992.

Rasmussen, C., Torn, M. S., and Southard, R. J.: Mineral assemblage and aggregates control carbon dynamics in a California conifer forest, Soil Sci. Soc. Am. J., 69, 1711-1721, 2005.

Rumpel, C. and Kögel-Knabner, I.: Deep soil organic matter - a key but poorly understood component of terrestrial C cycle, Plant Soil, 338, 143-158, 2011.

Schimel, D. S., Braswell, B. H., Holland, E. A., McKeown, R., Ojima, D. S., Painter, T. H., Parton, W. J., and Townsend, A. R.: Climatic, edaphic, and biotic controls over storage and turnover of carbon in soils, Global Biogeochem. Cy., 8, 279-293, 1994.

Schmidt, M. W. I., Torn, M. S., Abiven, S., Dittmar, T., Guggenberger, G., Janssens, I. A., Kleber, M., Kögel-Knabner, I., Lehmann, J., Manning, D. A. C., Nannipieri, P., Rasse, D. P., Weiner, S., and Trumbore, S. E.: Persistence of soil organic matter as an ecosystem property, Nature, 478, 49-56, 2011.

Sollins, P., Kramer, M. G., Swanston, C., Lajtha, K., Filley, T., Aufdenkampe, A. K., Wagai, R., and Bowden, R. D.: Sequential density fractionation across soils of contrasting mineralogy: evidence for both microbial- and mineral-controlled soil organic matter stabilization, Biogeochemistry, 96, 209-231, 2009.

Sollins, P., Spycher, G., and Glassman, C. A.: Net nitrogen mineralization from light- and heavy-fraction forest soil organic matter, Soil Biol. Biochem., 16, 31-37, 1984. 
Sollins, P., Spycher, G., and Topik, C.: Processes of soil organicmatter accretion at a mudflow chronosequence, Mt. Shasta, California, Ecology, 64, 1273-1282, 1983.

Sollins, P., Swanston, C., Kleber, M., Filley, T., Kramer, M., Crow, S., Caldwell, B. A., Lajtha, K., and Bowden, R.: Organic C and $\mathrm{N}$ stabilization in a forest soil: Evidence from sequential density fractionation, Soil Biol. Biochem., 38, 3313-3324, 2006.

Stuiver, M. and Polach, H. A.: Reporting of ${ }^{14} \mathrm{C}$ Data, Radiocarbon, 19, 355-363, 1977.

Stuiver, M., Reimer, P. J., and Braziunas, T. F.: High-precision radiocarbon age calibration for terrestrial and marine samples, Radiocarbon, 40, 1127-1151, 1998.

Swanston, C. W., Caldwell, B. A., Homann, P. S., Ganio, L., and Sollins, P.: Carbon dynamics during a long-term incubation of separate and recombined density fractions from seven forest soils, Soil Biol. Biochem., 34, 1121-1130, 2002.

Swanston, C. W., Torn, M. S., Hanson, P. J., Southon, J. R., Garten, C. T., Hanlon, E. M., and Ganio, L.: Initial characterization of processes of soil carbon stabilization using forest stand-level radiocarbon enrichment, Geoderma, 128, 52-62, 2005.

Torn, M. S. and Southon, J.: A new ${ }^{13} \mathrm{C}$ correction for radiocarbon samples from elevated- $\mathrm{CO}_{2}$ experiments, Radiocarbon, 43, 691694, 2001

Torn, M. S., Swanston, C. W., Castanha, C., and Trumbore, S. E.: Storage and turnover of organic matter in soil, in: BiophysicoChemical Processes Involving Natural Nonliving Organic Matter in Environmental Systems, edited by: Senesi, N., Xing, B., and Huang, P. M., John Wiley \& Sons, Inc, Hoboken, New Jersey, 219-272, 2009.

Torn, M. S., Trumbore, S. E., Chadwick, O. A., Vitousek, P. M., and Hendricks, D. M.: Mineral control of soil organic carbon storage and turnover, Nature, 389, 170-173, 1997.
Trumbore, S. E. and Zheng, S. H.: Comparison of fractionation methods for soil organic matter ${ }^{14} \mathrm{C}$ analysis, Radiocarbon, 38, 219-229, 1996.

Trumbore, S. E., Vogel, J. S., and Southon, J. R.: AMS ${ }^{14}$ C measurements of fractionated soil organic matter: an approach to deciphering the soil carbon cycle, Radiocarbon, 31, 644-654, 1989.

Trumbore, S. E.: Comparison of carbon dynamics in tropical and temperate soils using radiocarbon measurements, Glob. Biogeochem. Cycle, 7, 275-290, 1993.

Trumbore, S. E.: Radiocarbon and soil carbon dynamics, Annu. Rev. Earth Planet. Sci., 37, 47-66, 2009.

Trumbore, S.: Age of soil organic matter and soil respiration: Radiocarbon constraints on belowground C dynamics, Ecol. Appl., 10, 399-411, 2000.

Trumbore, S. E. and Czimczik, C. I.: An uncertain future for soil carbon, Science, 321, 1455-1456, 2008.

van Kessel, C., Nitschelm, J., Horwath, W. R., Harris, D., Walley, F., Luscher, A., and Hartwig, U.: Carbon-13 input and turn-over in a pasture soil exposed to long-term elevated atmospheric $\mathrm{CO}_{2}$, Glob. Change Biol., 6, 123-135, 2000.

Vogel, J. S.: A rapid method for preparation of biomedical targets for AMS. Radiocarbon, 34, 344-350, 1992.

von Lützow, M., Kogel-Knabner, I., Ekschmittb, K., Flessa, H., Guggenberger, G., Matzner, E., and Marschner, B.: SOM fractionation methods: Relevance to functional pools and to stabilization mechanisms, Soil Biol. Biochem., 39, 2183-2207, 2007. von Lützow, M., Kogel-Knabner, I., Ekschmittb, K., Matzner, E., Guggenberger, G., Marschner, B., and Flessa, H.: Stabilization of organic matter in temperate soils: mechanisms and their relevance under different soil conditions - a review, Eur. J. Soil Sci., 57, 426-445, 2006. 